\title{
Peculiar traits of wood in a leaning stem of Scots pine (Pinus sylvestris L.)
}

\author{
Aleksandra Jasińska $\bowtie$, Mirela Tulik \\ Warsaw University of Life Sciences - SGGW, Faculty of Forestry, Department of Forest Botany, Nowoursynowska 159, \\ 02-776 Warsaw, Poland, e-mail: aleksandra_jasinska@sggw.pl
}

\begin{abstract}
The paper analyses biometrical and anatomical traits of wood in a leaning stem of pine trees. For study purpose, five pine trees (Pinus sylvestris L.) with a visibly leaning stem were chosen. Wood samples were taken at three different stem heights, that is, below the stem curvature, at the curvature and above the curvature. Microscopic specimens were prepared and used for the following measurements: annual rings width, tracheids diameter and tracheids wall thickness. The measurements were performed for wood located on the lower side of the leaning stem and on the opposite side. Cytochemical staining was performed to identify the occurrence of laricinan. The results showed tracheids with a rounded shape and thick cell walls, helical cavities and intercellular spaces in wood located at curvature height on the lower side of the leaning stem. These traits indicate a severe compression wood that allowed pine trees to change their stem position in relation to the vector of gravity.
\end{abstract}

\section{KeY WORDS}

pine tree, tracheids, compression wood, normal wood, laricinan, helical cavities

\section{INTRODUCTION}

Environmental factors are believed to be important in the formation of a special type of wood referred to as reaction wood (RW) (Pillow and Luxford 1937). RW is formed by cambium when the main stem of a tree is displaced in relation to the vector of gravity owing to the prevailing wind, slope, snow or tree crown asymmetry (Barnett et al. 2014; Du and Yamamoto 2007; Timell 1986).

In conifers, RW is referred to as compression wood (CW) and usually formed on the lower side of an inclined stem and branches (Timell 1986). Its formation is caused by the increase in cambial activity, which in turn results in the occurrence of asymmetrical annual growth rings (the rings on $\mathrm{CW}$ side of the stem or branch are much wider than those observed in the wood on the opposite side).

The anatomy of $\mathrm{CW}$ is the same as that of normal wood $(\mathrm{NW})$ - it consists, amongst others, of tracheids - however, the greatest structural variability between CW and NW lies in tracheids of latewood. Latewood tracheids in NW are more or less rectangular in cross section, whereas those in CW are usually nearly circular. The result is intercellular spaces at the junction of four cells. Cell walls of $\mathrm{CW}$ tracheids are thicker than those in NW. The primary wall is the same as in NW; however, the secondary cell wall in CW lacks the inner- 
most S3 layer and consists of S1 and S2 layers only. The $\mathrm{S} 1$ layer is thicker, and the S2 layer consists of an outer $\mathrm{S} 2$ (L) region, which is rich in lignin, and an inner S2 region with helical cavities. Helical cavities affect some of the physical properties of the tissue because of the presence of a peculiar type of hemicellulose referred to as laricinan (Waterkeyn et al. 1982). The swelling of the glucan on wetting is believed to generate longitudinal stress occurring in $\mathrm{CW}$.

Dark colour in $\mathrm{CW}$ is caused by high content of lignin and 1,4- $\beta$-galactan and proportionately lower content of cellulose, mannan and xylan. Moreover, CW is characterised by unusually large amount of latewood in the wide section of the rings in comparison with the narrow section. Another trait of $\mathrm{CW}$, largely seen as not widespread, is the occurrence of traumatic vertical resin canals (Lee and Eom 1988).

As a result of the above modifications, CW cells may enlarge longitudinally and 'push' the branch or stem upright (Westing 1961, 1965; Timell 1986; Lin and Li 1993).

In general, there are two broad classes of CW: severe CW and mild CW (Yumoto et al. 1983). This classification is based on the helical cavities development, cell wall thickness, cell outline between the S1 and S2(L) layers, intercellular spaces and wood colour. The round tracheids, the higher level of lignification of the S2(L) region of tracheid walls and the presence of welldeveloped helical cavities with laricinan are believed to be the primary features of severe $\mathrm{CW}$ (Yumoto et al. 1983). Mild and severe CW are known to blend into each other, whereas mild CW refers to NW.

As structure and chemical composition of $\mathrm{CW}$ differs from NW, the quality of timber is low and possesses poor mechanical properties. On the basis of the knowledge on biology of $\mathrm{CW}$, forest service undertakes a lot of efforts to minimise CW detrimental effects.

Scots pine (Pinus sylvestris L.) is the main forest species in Poland and grows on more than $60 \%$ of forest area (Rozkrut 2017). It grows up to $35 \mathrm{~m}$ in height and 1 $\mathrm{m}$ stem diameter when mature. It is also one of the most commercially important wood species; its timber is important for both paper and pulp industries and widely used for the production of furniture and veneers.

The aim of the study was to examine the wood taken from the inclined stem of pine trees and we set forth the following hypothesis: Severe compression wood is present in the leaning stem of pine trees.

\section{MATERIAL AND METHOdS}

Research material was collected in the summer of 2013 from fresh coniferous stand of Rajgród Forest District (North-Eastern part of Poland). Five pine trees (P. sylvestris L.) aged 80-90 years with visibly leaning stems were selected for the study. Discs of wood were cut from each tree at three stem heights: below the stem curvature, at the curvature and above the curvature. Samples including the full complement of annual growth rings (from the pith to the wood near the cambium) were cut along one radial axis of each disc. Next, the samples were boiled in a mixture of water, glycerol and ethyl alcohol (1:1:1 ratio, $\mathrm{v} / \mathrm{v})$ to soften the wood and remove air. Longitudinal and transverse sections with the thickness of $30 \mu \mathrm{m}$ were prepared using 440E sliding microtome, placed on slides and mounted in distilled water. Microscopic observations were carried out using an OLYMPUS BX 61 microscope. Microscopic images were taken using a DP 70 camera and archived with CELL P software. Annual wood increment width was measured for all trees at each stem height and then averaged for 4-year time intervals. On the basis of these data, the wood increments with the highest asymmetry, that is, with significantly different width on both sides of the pith, were identified. At the curvature height, in annual wood increments with the highest asymmetry, three radial rows of tracheids were determined. In each randomly selected radial row, diameter and cell wall thickness were measured for tracheids of both early- and latewood. The biometrical parameters of 30 tracheids of wood located on the upper side of the stem and 30 tracheids of wood located on the lower side of the stem were compared, in the both early- and latewood. Using $t$-test at $\mathrm{p}<0.05$, the significance of the differences in average cell wall thickness and tracheid diameter was investigated.

In order to detect the laricinan, cytochemical staining was performed. The annual wood increment with round tracheids was treated with a $0.1 \%$ water solution of aniline blue for 10 min (Broda 1971). It was then observed under the OLYMPUS BX 61 microscope equipped with a UV filter. Light fluorescence of S2 cell wall region indicates the occurrence of laricinan. Control staining was also performed for the annual increment located on the opposite side of the pith. 


\section{Results AND DISCUSSION}

\section{Peculiar traits of wood at the stem curvature height}

On the lower side of the leaning stem, wood in wider annual increments (than those on the opposite side) was brown, indicating increased lignin content, which is one of the traits of CW (Sinnot 1952; Timell 1986). Morphometric measurements showed the presence of asymmetric rings at this height, that is, with significantly larger width $(p<0.05)$ on the lower side of the leaning stem. Over a 20 -year period, the average width of a ring was $3.86 \mathrm{~mm}$ (SD 1.44) on the lower side of the stem and $1.04 \mathrm{~mm}$ (SD 0.86) on the opposite side. The asymmetric radial growth is related to the occurrence of CW (Duncker and Spiecker 2008), although it does not explicitly indicate its presence (Westing 1961, Riech and Ching 1970). Steucek and Kellogg (1972) proved that when the stem orientation is changed in relation to the vector of gravity owing to stimuli, an asymmetry of annual rings width can be observed; however, it is not always related to the presence of $\mathrm{CW}$.

In earlywood in the rings formed on the upper side of the leaning stem, the average cell wall thickness of tracheids was $3.33 \mu \mathrm{m}$ (SD 0.65), which was significantly thinner than that on the opposite side of the pith, for which the average cell wall thickness was $3.78 \mu \mathrm{m}$ (SD 0.58). In latewood in the rings formed on the upper side of the leaning stem, the average cell wall thickness of tracheids was $4.68 \mu \mathrm{m}$ (SD 2.14) and that on the opposite side was $5.42 \mu \mathrm{m}$ (SD 0.97). Tracheid cell walls on the lower side of the leaning stem in latewood were significantly thicker than those on its upper side. Significantly thicker tracheid cell walls, in particular in latewood, can be considered as a characteristic trait of CW (Pillow and Luxford 1937; Tulik and Jura-Morawiec 2011). However, not the entire annual increment is formed by cells with compressive traits, and in conifers, compressive traits usually apply to latewood tracheids (Ruelle 2014).

The average diameter of tracheids was $27.29 \mu \mathrm{m}$ (SD 4.71) in earlywood on the upper side of the leaning stem and $26.13 \mu \mathrm{m}$ (SD 4.41) on the opposite side. The difference between the average values was statistically insignificant. The average diameter of tracheids of latewood was $11.53 \mu \mathrm{m}$ (SD 2.78) on the upper side of the leaning stem and was significantly higher (16.33 $\mu \mathrm{m}, \mathrm{SD} 2.33$ ) on the opposite side.
Round tracheids of latewood and intercellular spaces in wood were observed at the curvature height on the lower side of the stem (Fig. 1; for comparison with NW, see Fig. 4). The cytochemical staining performed for wood with round latewood tracheids showed modifications in the structure of the S2 layer of their secondary cell walls, that is, visible autofluorescence of lignin in the S2(L) layer and fluorescence of laricinan in helical cavities (Fig. 2). It should be noted that laricinan does not occur in NW (Zhang et al. 2016; Włoch and Hejnowicz 1983). In CW, its content varies from $2 \%$ to $4 \%$ (Włoch and Hejnowicz 1983). Moreover, the presence of laricinan in helical cavities indicates severe CW (Yumoto et al. 1983). Owing to the fact that laricinan is characterised by water absorption and swelling, it generates longitudinal stress (Fagerstedt et al. 2014; Włoch and Hejnowicz 1983). Therefore, we can assume that laricinan allows leaning pine stems to correct their position in relation to the vector of gravity.

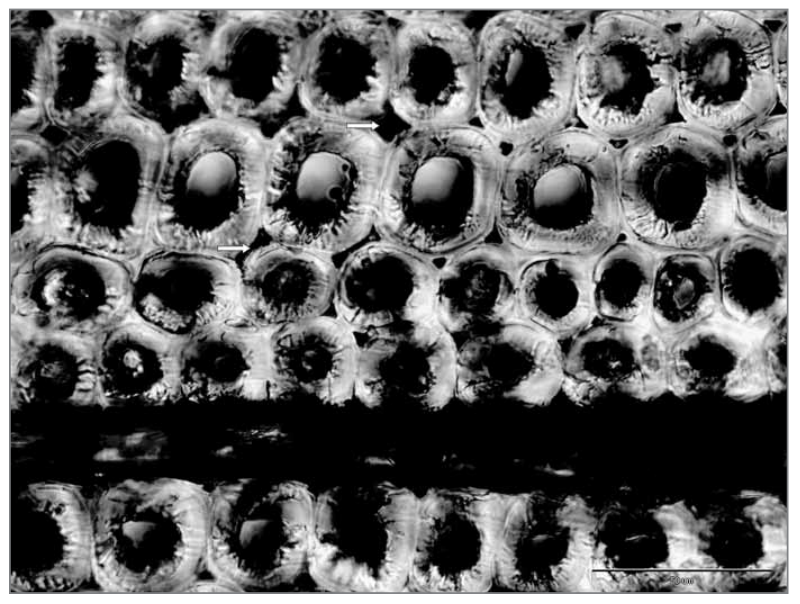

Figure 1. Cross section of wood from the lower side of the leaning stem. Visible round-shaped tracheids and intercellular spaces (as indicated by arrows).

The analysis of the longitudinal sections of wood from the lower side of leaning pines showed bent tips of tracheids (Fig. 3). Bamber (2001) stipulates that tracheids with bent tips may show higher mechanical strength in comparison with those observed in NW.

In the subsequent years, after the period of the highest asymmetry of annual rings, no significant differences in the annual growth width were observed on either side of the pith. The tracheids were rectangular, 
arranged in regular radial rows and did not show traits of the compression tracheids.

A

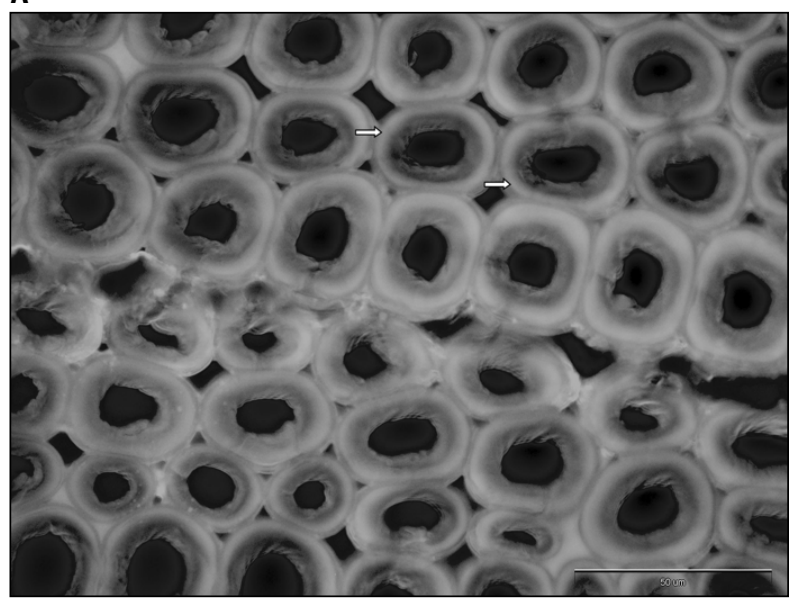

B

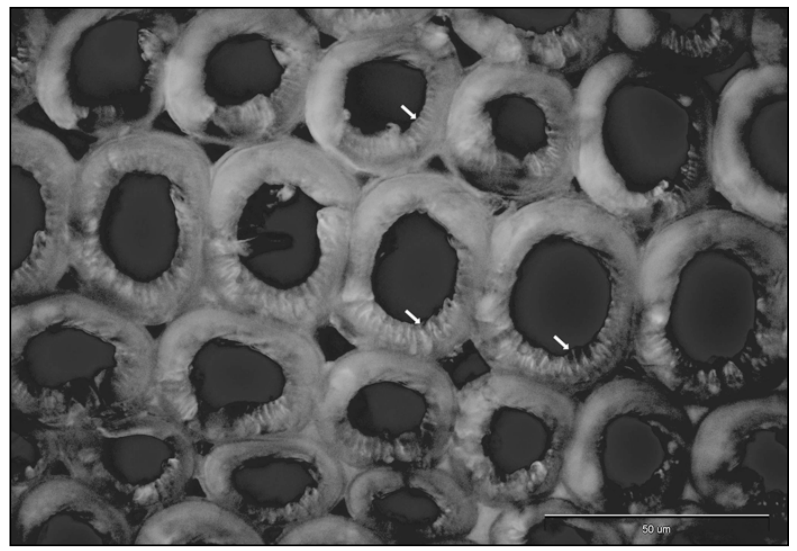

Figure 2. Cross section of wood from the lower side of the leaning stem: A - autofluorescence of lignin in an outer $\mathrm{S} 2(\mathrm{~L})$ region of the tracheid cell walls is indicated by arrows; $\mathrm{B}-$ Fluorescence of laricinan in an inner S2 region of the secondary cell walls is indicated by arrows

\section{Traits of wood above}

\section{and below the stem curvature}

In the stem of one of the pine trees, the rings of wood below and above the curvature showed asymmetry in the period when $\mathrm{CW}$ was formed at the stem curvature height, that is, the annual growth was significantly wider on the upper side of the leaning stem. Thus it can be assumed that these asymmetrical increments were formed to stabilise the stem, as indicated by Alméras and Fournier (2009).

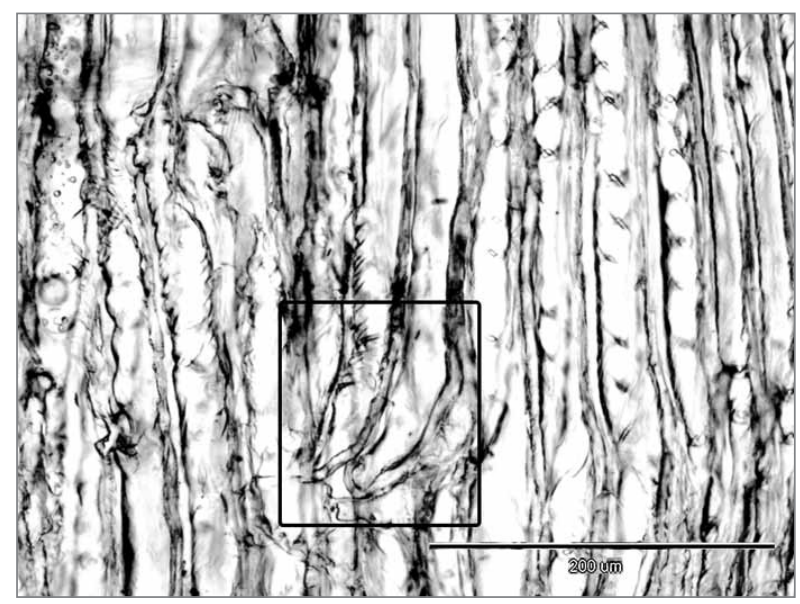

Figure 3. Radial section of compression wood. Visible deformed tracheid tips (as indicated by square)

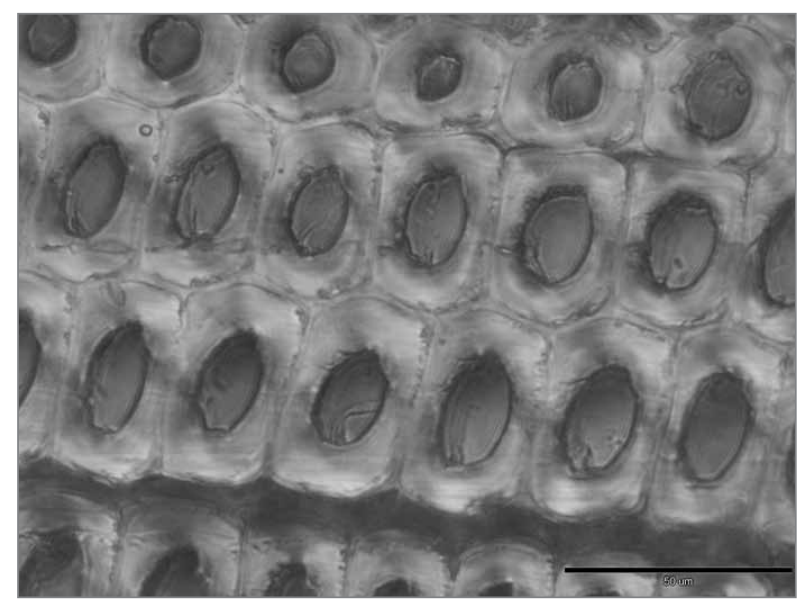

Figure 4. Cross section of normal wood. Visible regular rows of rectangular-shaped tracheids, no intercellular spaces

A structural analysis of wood on both sides of the pith showed traits characteristic of NW, that is, rectangular, adjacent tracheids (Fig. 4). No laricinan was found in the S2 layer of the secondary cell wall.

\section{Conclusions}

1. Tracheids with a round shape and thick cell walls, helical cavities and intercellular spaces have been found in the wider rings located on the lower side of the leaning stem at curvature height.

2. As the severe CW has only been observed at curvature height, it may be assumed that the correlation between degree of stem lean and severe CW forma- 
tion exists. However, this idea requires confirmation with experimental studies. Knowledge of such correlation allows to use different parts of the stem for the production of different products of wood industries.

\section{Acknowledgement}

The article has been revised by linguist of KMK Biuro Tłumaczeń Elżbieta Pląskowska.

\section{References}

Alméras T., Fournier M. 2009. Biomechanical design and long-term stability of trees: Morphological and wood traits involved in the balance between weight increase and the gravitropic reaction. Journal of Theoretical Biology, 256 (3), 370-381.

Bamber K.R. 2001. A general theory for the origin of growth stresses in the reaction wood: How trees stay upright. IAWA Journal, 22 (3), 205-212.

Broda B. 1971. Metody histochemii roślinnej. Państwowy Zakład Wydawnictw Lekarskich, Warszawa.

Du S., Yamamoto F. 2007. An overview of the biology of reaction wood formation. Journal of Integrative Plant Biology, 49 (2), 131-143.

Duncker P., Spiecker H. 2008. Cross-sectional compression wood distribution and its relation to eccentric radial growth in Picea abies [L.] Karst. Dendrochronologia, 26, 195-202.

Fagerstedt K.V., Mellerowicz E., Gorshkova T., Ruel K., Joseleau J.P. 2014. Cell wall polymers in reaction wood. In: The biology of reaction wood (eds.: B. Gardiner, J. Barnett, P. Saranpaa, J. Gril). SpringerVerlag, Berlin Heidelberg, 37-106.

Lee P.W., Eom Y.G. 1988. Anatomical comparison between compression wood and opposite wood in a branch of Korean pine (Pinus koraiensis). IAWA Journal, 9 (3), 275-284.

Lin J.X., Li Z.L. 1993. Comparative anatomy of normal wood and compression wood of masson pine (Pinus massoniana) (in Chinese with an English abstract). Acta Botanica Sinica, 35, 201-205.

Pillow M.Y., Luxford R.F. 1937. Structure, occurrence, and properties of compression wood.US Department of Agriculture.
Riech F.P., Ching K.K. 1970. Influence of bending stress on wood formation of young Douglas-Fir. Holzforschung, 24, 68-70.

Ruelle J. 2014. Morphology, anatomy and ultrastructure of reaction wood. In: The biology of reaction wood (eds.: B. Gardiner, J. Barnett, P. Saranpaa, J. Gril) Springer-Verlag, Berlin Heidelberg, 13-35.

Sinnot E.W. 1952. Reaction wood and the regulation of tree form. American Journal of Botany, 39, 69-78.

Steucek G.L., Kellogg R.M. 1972.The influence of a stem discontinuity on xylem development in Norway spruce, Picea abies. Canadian Journal of Forest Research, 2, 217-222.

Rozkrut D. 2017. Mały Rocznik Statystyczny Polski 2017. Zakład Wydawnictw Statystycznych, Warszawa.

Timell T.E. 1986.Compression wood in gymnosperms. Springer-Verlag, New York.

Tulik M., Jura-Morawiec J. 2011. Reaction wood and tree crown architecture (in Polish with English summary). Sylwan, 155, 808-815.

Waterkeyn L., Caeymaex S., Decamps E. 1982.Callose in compression wood tracheids of Pinus and Larix. Bulletin de la Societe Royale de Botanique de Belgique,115 (2), 149-155.

Westing A.H. 1961. Changes in radial symmetry in the leaders of eastern white pine following inclination. Journal of Forestry, 56, 17-19.

Westing A.H. 1965. Formation and function of compression wood in gymnosperms. The Botanical Review, 31, 381-480.

Włoch W., Hejnowicz Z. 1983. Location of laricinan in compression wood tracheids. Acta Societatis Botanicorum Poloniae, 52 (3/4), 201-203.

Yumoto M., Ishida S., Fukazawa K. 1983. Studies on the formation and structure of the compression wood cells induced by artificial inclination in young trees of Picea glauca-IV. Gradation of the severity of compression wood tracheids. Research Bulletins of the College Experiment Forests, Hokkaido University, 40, 409-454.

Zhang M., Chavan R.R., Smith B.G., McArdle B.H., Harris P.J. 2016. Tracheid cell-wall structures and locations of $(1 \rightarrow 4)-\beta$-D-galactans and $(1 \rightarrow$ $3)-\beta$-D-glucans in compression woods of radiata pine (Pinus radiata D. Don). BMC Plant Biology, $16(1), 194$. 